\title{
MANAGEMENT ISSUES IN INDIAN BIOSPHERE RESERVES, WITH SPECIAL REFERENCE TO ALTERNATIVE LIVELIHOOD OPTIONS FOR THE DEPENDENT POPULATION
}

\author{
R.K. RAI \\ Member-Secretary, Indian National MAB Committee \\ Ministry of Environment \& Forests, New Delhi, India
}

Proceedings of the South and Central Asian MAB Meeting of Experts on Environmental Conservation, Management and Research, Hikkaduwa, Sri Lanka 15-18 October 2002

\section{Introduction}

The biosphere reserve programme in India was initiated in 1986. The programme was intended to develop (within the natural and social sciences) a basis for the rational use and conservation of resources of the sites designated as biosphere reserves based on the criteria set by UNESCO. The approach emphasizes that, while meeting the needs of dependent population, the importance of maintenance of the structure and functioning of ecological systems be kept in mind. The mode of reaction of ecosystems is monitored when exposed to human intervention including the impact of man on the environment and vice-versa. The set objectives are gradually being achieved through targeted research and management interventions, largely through the economic well-being of the dependent population. This helps in harnessing their support for conservation.

\section{Concept :}

Planners, scientists, managers and local people participate in evolving a programme to manage land and water to meet human needs, and at the same time conserve natural processes and ecological resources of representative ecosystems. This is achieved through sustainable resource use, without reducing the potential for future use of the resource. Promotion of economic development, which is culturally, socially and ecologically sustainable, is made mandatory. Development of community spirit in the management of natural resources is an important aspect of the programme.

\section{Biosphere Reserves in India}

The geographical location of India which is between $8^{\circ} 4^{\prime} \mathrm{N}$ and $37^{\circ} 6^{\prime} \mathrm{N}$, provides a wide latitudinal spread, and permits a wide range of variations in temperature. Mountainous regions covering an area close to 100 million hectares, arid and semi-arid zones spreading over 30 million hectares and the long coastline over $7,000 \mathrm{~km}$, make up the diversity of the physical environment, which coupled with 
varied precipitation, constitute a rich landscape diversity. These bio-physical features have contributed to India being recognized as one of the 12 mega biodiverse countries.

The loss of biodiversity is due mainly to economic development activities with associated resource degradation such as land, forests, water and air. Conservation of biodiversity requires knowledge on what to conserve, how to conserve and where to conserve. In fact, ex-situ conservation measures are of little value for countries like India. The only approach by which biodiversity can be protected is through in-situ conservation measures, using the 'Biosphere Reserve' concept. Realizing this fact, the Indian Government has designated 13 biosphere reserves in the country in different bio-geographic zones, of which 3 have been designated on the World Network of Biosphere Reserves by UNESCO.

\section{Vision}

To conserve the globally significant biodiversity and pristine landscapes through the concept of biosphere reserves, while allowing for the sustainable use of natural resources with the participation of stakeholders.

\section{Mission}

Reduction of pressure to these ecosystems from various anthropogenic activities by developing alternative livelihood options, targeted research and protection through the following set objectives:

\section{Objectives:}

- To conserve the diversity and integrity of plants and animals within natural ecosystems;

- To safeguard the genetic diversity of species on which their continuing evolution depends;

- To provide areas for multi-faceted research and monitoring;

- To provide facilities for education and training; and

- To ensure the sustainable use of natural resources through the most appropriate technologies.

\section{Main Stakeholders and Their Needs / Roles}

\section{The Government}

The Government of India has recommended the Indian National MAB Committee to advise on policy and programme formulation, to lay down guidelines for preparation and approval of Management Action Plans, to oversee implementation, monitoring and evaluation, approve new Biosphere Reserves etc. The Central 
Government assumes responsibility for financial assistance for implementation of the approved items of activities, technical expertise and know-how including trained personnel; and for detailed guidelines covering all aspects of management for implementation by the State/UTs machinery followed by effective monitoring and supervision.

\section{The Local Communities, Scientists and the Tourists:}

Introduction of management interventions which include the management of the buffer zone in a manner that ensures local community participation in conservation and the sustainable utilization of the resources, as well as evolvement of ways and means by which the economic well-being of local people is secured. It also involves development of management measures that protect the core zone by relieving pressures on the buffe zone.

\section{Inter-departmental Coordination:}

As the reserves are usually very large and sometimes cover many civil districts, and are administratively complex, coordination among various departments is ensured by involving representatives of various departments in the Steering Committees and in programme formulations.

\section{Strategies:}

\section{Zoning}

Each reserve has been divided into various user zones to facilitate effective management. The core zone (total protection), the buffer zone (sustainable use), and the transition zone (multiple use zone) are well defined. Tourism zones are demarcated and effectively regulated.

\section{Legal framework}

At present, Biosphere Reserves are established within the framework of existing laws dealing with conservation, including the Wildlife (Protection) Act of 1972.

\section{Economic activities:}

Development of a comprehensive resource inventory, augmentation of required expertise, and prioritisation of activities with reference to additional income generating activities are given priority. These include the popularisation of energy alternatives, rangelands and grassland management, habitat improvement, animal husbandry, aquaculture, agriculture, and encouragement for continuance of 
traditional crops including wild relatives of cultivated species for agro-biodiversity conservation, and adoption of technologies that make resource utilisation sustainable.

Emphasis is given to the following:

\section{Value addition activities}

Activities such as providing rope making machines using local material, leaf plate making machines, etc. have helped in enhancing the income of local people.

\section{Setting up of pilot plots}

Ecologically appropriate forestry, cultivation of medicinal plants, traditional agriculture and horticulture, and facilities for ex-situ conservation measures are helping in resource augmentation and income generation.

\section{Sustainable use of threatened resources}

Development of approaches and practices that result in the sustainable use of economically important but threatened species are given priority.

Rehabilitation of landscapes of threatened species and ecosystems

Landscapes within the reserve which are the habitat of threatened species are regenerated using local and threatened species.

\section{Socioeconomic upliftment of local communities}

Creation of facilities for improved health care such as immunization, and the supply of safe drinking water, as well as the development of small-scale household industries for manufacturing crafts based on local resources, have given confidence to the local communities.

\section{Compensation}

Acquisition of additional critical habitats that ensure longterm maintenance of ecosystem health through appropriate rehabilitation packages is being attempted through suitable compensation.

\section{Maintenance and protection of corridor areas}

Corridor areas are given priority attention to augment continuity of ecological processes and facilitate the movement of wildlife. 


\section{Development of a communication and network system}

Development of viable linkages is being gradually attempted between various biosphere reserves, stakeholders, and government and nongovernment agencies operating in the region to facilitate protection measures and exchange of information.

\section{Development of ecotourism}

To augment people's appreciation for nature and generate income through ecotourism.

The overall thrust of management is to provide means for the people who live and work within and around BRs to attain a balanced relationship with the natural world, and to pave the way for a more sustainable future, while contributing towards the needs of the society. Local community participation in planning and management is made mandatory.

\section{Research, Monitoring and Evaluation:}

Research and monitoring are important components which provide the most important database necessary for management. In order to compile all the research based data, identified institutions have been assigned the task of compiling all the relevant data to make it more useful management. Emphasis is given to landscape level monitoring through remote sensing, and species and ecosystem level monitoring through research.

\section{Education, Awareness, Training and Capacity Building:}

Education, awareness, training and capacity building of the local communities, visitors and the general public are essential components of the management of Biosphere Reserves. Audio-visuals depicting the role of Biosphere Reserves in protecting life-supporting systems, and the need to care for the earth through the sustainable use of resources are given priority. Training is given to local youth in skills that enable them to undertake participation, development, and demonstration of integrated resource management with people's participation in buffer zone villages. Training and education of personnel responsible for management are also assured in order to enhance knowledge of modern concepts, and understanding about conservation and sustainable use of biological resources.

\section{Conclusion}

Conservation of natural resources of global significance can be ensured through economic incentives and livelihood options for the local population which largely depends on the local resources. 